DOI: 10.20472/LPC.2018.002.006

\author{
ADELA KRATENOVA \\ Nottingham Trent Uviversity, United Kingdom
}

\title{
INTERNATIONAL LEGAL RELATIONS IN TROUBLED TIMES AND THEIR IMPACT ON SUBSTANTIVE ELEMENTS OF INTERNATIONAL TRADE
}

\begin{abstract}
:
Trade between different countries forms a significant part of national economic development worldwide. The significance of the interdependence of countries is increasing with rising globalisation (Helpman, 2011). To facilitate cross-border cooperation, including trade, countries form associations and other cooperative units with established rules, often with economic advantages, amongst the Member States. The European Union (the "EU") and the European Economic Area (the "EEA") are relevant examples of the above cooperation. One of the main objectives of the EU is the establishment of an internal market without internal frontiers ensuring the free movement of goods, persons, services and capital (Consolidated version of the Treaty on the Functioning of the European Union 2012, Art. 26). The EEA unites the EU countries with Iceland, Liechtenstein and Norway, allowing the non-EU members to enjoy the free movement of goods, persons, services and capital without internal frontiers similarly (Agreement on the European Economic Area, 1994, Art. 1). The United Kingdom (the "UK") is a Member State of the EU (and therefore the EEA) allowing it to be part of the concept of an internal market. However, the situation for the UK might be changed in the future due to the UK's EU membership referendum which took place on 23rd June 2016 resulting in the majority of voters expressing their desire for the UK to leave the EU (the UK leaving the EU also "BREXIT").

BREXIT will inevitably impact various aspects of the existing legal establishment. The area of Private international law (the 'PIL'), encompassing the determination of applicable law, jurisdiction of courts and enforcement of foreign judgement, will be influenced to a significant extent. The paper will briefly examine the current legal establishment and the options the UK has concerning future arrangements of the PIL rules. Further, the paper will investigate future jurisdictional competence, enforceability of foreign judgements taking into consideration the development in a field of international arbitration, specifically the enforcement of arbitration awards and control of arbitration proceedings in the BREXIT context. The paper aims to identify the challenges brought by the potential removal of the current EU PIL regime which can be considered as a 'safety net'.
\end{abstract}

\section{Keywords:}

Brexit, Private International Law, International Commercial Law, Trade, Enforcement

JEL Classification: K00, K33, K20 